University of Wollongong

Research Online

Faculty of Social Sciences - Papers (Archive) Faculty of Arts, Social Sciences \& Humanities

$1-1-2013$

Factors that influence consumption of fish and omega-3 enriched foods: a survey of Australian families with young children

Setyaningrum Rahmawaty

University of Wollongong

Karen Charlton

University of Wollongong, karenc@uow.edu.au

Philippa Lyons-Wall

Edith Cowan University, philippa@uow.edu.au

Barbara J. Meyer

University of Wollongong, bmeyer@uow.edu.au

Follow this and additional works at: https://ro.uow.edu.au/sspapers

Part of the Education Commons, and the Social and Behavioral Sciences Commons

Research Online is the open access institutional repository for the University of Wollongong. For further information contact the UOW Library: research-pubs@uow.edu.au 


\title{
Factors that influence consumption of fish and omega-3 enriched foods: a survey of Australian families with young children
}

\begin{abstract}
Aim: The present study aimed to identify factors that influence the consumption of fish and foods that are enriched with omega-3 long-chain polyunsaturated fatty acids (n-3 LCPUFA), in order to inform the development of effective nutrition education strategies. Methods: A cross-sectional, 10-item selfadministered survey was conducted to 262 parents of children aged 9-13 years from a regional centre in New South Wales. Parents were asked questions related to frequency of consumption, and to identify factors that either encouraged or prevented the provision of fish/seafood and/or n-3 LCPUFAenriched foods for their families. Results: Salmon, canned tuna, prawn and take-away fish were the most commonly eaten variants of fish/seafood, at approximately once a month. Perceived health benefits and the influence of media and health professionals in health promotion were identified as the primary motivators for consumption of fish/seafood and foods enriched with n-3 LCPUFA. Among families who consume fish, taste was valued as having a major positive influence, as well as preferences of individual family members, but the latter was perceived as an obstacle in non-fish consumers. Price was the main barrier to consumption of fresh, but not canned, fish and n-3-enriched foods, in both those that do and do not consume these foods. Conclusion: Despite Australian parents' knowledge of the health benefits n-3 LCPUFA, only a fifth of households meet the recommended two serves of fish per week, hence nutrition education strategies are warranted.
\end{abstract}

\section{Keywords}

influence, that, survey, australian, families, young, children, enriched, foods, 3 , factors, omega, fish, consumption

\section{Disciplines}

Education | Social and Behavioral Sciences

\section{Publication Details}

Rahmawaty, S., Charlton, K., Lyons-Wall, P. \& Meyer, B. J. (2013). Factors that influence consumption of fish and omega-3 enriched foods: a survey of Australian families with young children. Nutrition and Dietetics, 70 (4), 286-293. 


\title{
Factors that influence consumption of fish and omega-3 enriched foods: A survey of Australian families with young children
}

\author{
Setyaningrum RAHMAWATY ${ }^{1,2}$, Karen CHARLTON ${ }^{2}$, \\ Philippa LYONS-WALL ${ }^{3}$, Barbara J MEYER ${ }^{1,2}$ \\ ${ }^{1}$ Metabolic Research Centre, University of Wollongong: ${ }^{2}$ School of Health Sciences, \\ University of Wollongong, Wollongong, New South Wales, and ${ }^{3}$ School of Exercise and Health Sciences, \\ Edith Cowan University, Perth, Western Australia, Australia
}

\begin{abstract}
Aim: The present study aimed to identify factors that influence the consumption of fish and foods that are enriched with omega-3 long chain polyunsaturated fatty acids (n-3 LCPUFA), in order to inform the development of effective nutrition education strategies.

Methods: A cross-sectional, ten-item self-administered survey was conducted in 262 parents of children aged 9-13 years from a regional centre in '[removed for blind peer review]'. Parents were asked questions related to frequency of consumption, and to identify factors that either encouraged or prevented the provision of fish/seafood and/or n-3 LCPUFA enriched foods for their families.

Results: Salmon, canned tuna, prawn and take-away fish were the most commonly eaten variants of fish/seafood, at approximately once a month. Perceived health benefits, and the influence of media and health professionals in health promotion were identified as the primary motivators for consumption of fish/seafood and foods enriched with n-3 LCPUFA. Among families who consume fish, taste was valued as having a major positive influence, as well as preferences of individual family members, but the latter was perceived as an obstacle in non-fish consumers. Price was the main barrier to consumption of fresh, but not canned, fish and n-3 enriched foods, in both those that do and do not consume these foods.

Conclusion: Despite Australian parents' knowledge of the health benefits n-3 LCPUFA, only a fifth of households meet the recommended two serves of fish per week, hence nutrition education strategies are warranted.
\end{abstract}

Key words: barriers, beliefs, fish consumption, omega-3 enriched food, parents, promoting factors.

\footnotetext{
S. Rahawaty, MHSc, PhD student

K. Charlto, PhD APD, A/Professor

P. Lyons-Wall, PhD APD, A/Professor

B.J. Meyer, PhD, RNutr, A/Professor

Correspondence: B.J. Meyer, School of Health Sciences, University of Wollongong, Northfields Ave, Wollongong

NSW 2522, Australia. Email: bmeyer@uow.edu.au
} 


\section{INTRODUCTION}

The health benefits of consuming fish and/or seafood and foods enriched with n-3 have been widely reported in school children and adolescents, with outcomes including improvements in cognitive performance and academic achievement, ${ }^{1-5}$ atheroprotective lipid profiles, ${ }^{6}$ improved cardiovascular risk factors ${ }^{7}$ and possibly the prevention of obesity-related chronic diseases. ${ }^{8}$ These benefits are primary attributed to the high content of n-3 LCPUFA, eicosapentaenoic acid (EPA) and docosahexaenoic acid (DHA). These fatty acids are insufficiently de novo synthesized in the human body, ${ }^{9,10}$ thus, must be obtained from foods containing preformed EPA and DHA, such as fish and/or seafood ${ }^{11,12}$ as well as foods enriched with $n-3 .{ }^{13}$ Fish consumption is a valid predictor for EPA and DHA concentration in serum phospholipid. ${ }^{14,15}$ Likewise, the consumption of omega-3 enriched foods (e.g. bread, egg, milk and dips) leads to a significantly increased concentration of EPA and DHA levels in serum phospholipids ${ }^{16,17}$ plasma $^{18,19}$ and erythrocytes. $^{20}$

The Australian Dietary Guidelines advise children to consume a half to one serving of fish each day, with a serve size equivalent to 80 - 120 grams of cooked fish fillet for optimal brain development and cardiovascular health. ${ }^{21}$ Other agencies such as the National Heart Foundation of Australia ${ }^{22,23}$ recommend higher intakes ( 2 or 3 serves of $150 \mathrm{~g}$ per serve size of fatty fish per week), as well as food and drinks enriched with n-3 LCPUFA.

Fish and/or seafood products have been reported to provide $88 \%$ of DHA, $78 \%$ of EPA and $79 \%$ of total n-3 LCPUFA in the diets of Australian children. ${ }^{12}$ Consumers of fish ate on average $59 \mathrm{~g}$ (SD $48 \mathrm{~g}$ ) per day, which enabled them to meet approximately $70 \%$ of the suggested dietary target (SDT) for $\mathrm{n}-3$ LCPUFA. ${ }^{12}$ However, in a nationally representative sample of children, only a fifth had eaten fish within the two days of dietary reporting. ${ }^{24,25}$ 
Additionally, less than $7 \%$ of the Australian children consumed foods enriched with $n-3,{ }^{25}$ which has previously been proposed as a strategy to increase population-intake of n-3 LCPUFA. ${ }^{26,27}$ In countries with traditionally low fish consumption such as Australia, ${ }^{25}$ n-3 enriched foods may play an important role in meeting the dietary recommendation for n-3 LCUFA intake for optimal health. Such foods are available in supermarkets in Australia, and include various n-3 enriched breads, eggs, milk and yoghurts.

Food consumption patterns of children are largely influenced by individual food preferences ${ }^{28}$ which in turn may be influenced by parental influences. ${ }^{29}$ Children are known to model behaviour related to food selection on the dietary habits of their parents. ${ }^{30,31}$ For example, children's fish consumption patterns are similar to those of their mother. ${ }^{32}$

The development of food-acceptance patterns of a child that tend to persist into adulthood is dependent to a large extent on the home environment. ${ }^{33}$ Involvement of adolescents (9-14 years old) at the family dinner table improved the quality of their diet. ${ }^{34}$ It is suggested that interventions targeting healthy eating behaviours in children should involve family members in order to modify home environments, whereby parents and other family members in the household also change dietary behaviours to include healthier options ${ }^{30,35}$ that in the case of increased n-3 intake would include fish and n-3 enriched foods. Fish and/or seafood consumption is influenced by many factors. Numerous identified barriers in adults include difficulty purchasing, preparing and cooking fish; the high cost; the unpleasant physical properties of some characteristics of fish (e.g. bones and smell); a low awareness of the health benefits associated with fish consumption; a limited supply and quality of fresh fish; preferences of other family members; the lack of product choice; unpleasant taste; low socioeconomic background; as well as environmental concerns related to sustainability and the presence of pollutants in the food 
supply. ${ }^{36-38}$ A negative attitude towards both the smell and the accompaniments, and fear of finding bones has been reported as barriers for fish consumption in adolescents. ${ }^{39}$ Food neophobia, 'avoidance of and reluctance to taste of unfamiliar food ${ }^{40}$ has also been identified as a factor that predicts low fish consumption in young adults. ${ }^{41}$

A number of consumer surveys have investigated fish consumption patterns in groups across Australia, ${ }^{42-45}$ while others have identified consumers' intentions to purchase foods enriched with $n-3 .^{46,47}$ The current study is the first one to identify factors which influence parents or primary caregivers decisions to provide fish/seafood and/or n-3 enriched foods to their family. Findings of this study will inform the development of more targeted health messages to improve n-3 LCPUFA intake in Australian children.

\section{METHODS}

A cross sectional survey was conducted from June to September 2011 in Wollongong, New South Wales, to identify factors relating to parents or primary caregivers' behaviours in preparing fish and/or seafood and n-3 enriched food products for their family. Two methods of questionnaire administration were offered, either a paper-based survey or an online format using the Survey Monkey tool. A survey questionnaire was developed based on published literature related to barriers and promoting factors affecting consumption of fish and n-3 enriched foods. Ten closed questions addressed about frequency of consumption of various types of fresh or frozen and canned fish/seafood and n-3 enriched food products (three items), barriers and promoting factors for consuming these foods (three items), and preferences for nutrition education activities aimed at improving children's n-3 LCPUFA intake (four items). An 8-point Likert scale was used for participants' responses to frequency of consumption (almost never, 
once a month, 2 or 3 times a month, once a week, 3 or 4 times a week, once a day and not applicable), and a 5-point scale for listed factors that influence consumption patterns (have a large positive influence, some positive influence, neutral, some negative influence and have a large negative influence). The questionnaire was pilot-tested in 7 parents (data not shown) prior to the main survey.

A convenient sample of 262 participants (102 and 160 filled out online and paper-based survey respectively) was recruited using advertisements at the University of Wollongong, child minding centres, shopping centres, mother groups, public offices and local media units in Wollongong. Respondents who were eligible to participate in this survey were parents or primary caregivers who have a child aged 9 to 13 years.

Data was analysed according to categorization into three patterns of fish consumption: frequent eaters (respondents that consumed fish and/or seafood as per the recommendation of 2 or more servings per week), occasional eaters (fish and/or seafood less than twice per week) and non-fish eaters. Participants' responses related to barriers and promoting factors for fish and/or seafood and n-3 enriched foods were reported in two categories, positive and negative factors (response to neutral was not shown). This study was approved by the the Human Research Ethics Committee at the University of Wollongong.

\section{RESULTS}

Of the 262 participants (102 and 160 filled out online and paper-based survey respectively), three-quarters were Australian (76\%) with the remainder from various nationalities and most were between 35-44 years of age (62\%). Almost all (90\%) parents or primary caregivers reported being consumers of fish/ seafood and $20 \%$ of households meet the recommended 
two serves of fish per week. Of those who ate fish, approximately three-quarters consumed it at least once a week, and a third consumed it twice or more per week (Table 1).

Certain of types of fresh or frozen fish, including mackerel and herring (77\%), anchovies and sardines (76\%), and oyster (66\%) were almost never eaten (Table 2). Similarly, variants of canned fish or seafood, such as herring and shellfish (80\%), mackerel (79\%), prawn and fish paste $(78 \%)$, oysters $(76 \%)$, anchovies $(74 \%)$, and sardines $(70 \%)$ were infrequently consumed (Table 3). The most frequently consumed types of fish were fresh tuna, prawns and salmon, while canned fish favourites included tuna and salmon (Table 2 and 3). In the occasional consumers, fresh prawns (64\%) and take-away fried fish and chips (60\%) were the most commonly eaten, followed by tuna (34\%) and shellfish (26\%), whilst in this group, canned fish choices included tuna (59\%) and salmon (41\%), followed by sardines (14\%) and anchovies (11\%) (Table 2 and 3).

Figure 1 shows the barriers and promoting factors for consuming fresh or frozen and canned fish/seafood according to the three categories of consumption. In all groups, health benefit was the most commonly reported influence (37\% to $80 \%)$, followed by media $(20 \%$ to $39 \%$ ), health promotion activities (15\% to $36 \%$ ), and advice from a health professional (19\% to $33 \%)$. Identified barriers included dislike for bones (24\% to $58 \%)$, unpleasant smell $(30 \%$ to $40 \%$ ) and pollutant content ( $22 \%$ to $39 \%$ ). Of the respondents who were consumers of fish, taste was the second most important influence ( $33 \%$ to $57 \%$ ); in contrast it was a barrier in individuals who were non-consumers (19\% to $22 \%)$. Almost half of frequent consumers were influenced by preferences of other family members (fresh or frozen fish (44\%), canned fish (37\%)), while this was rated as a barrier in respondents who were occasional $(28 \%)$ or non-consumers $(22 \%)$. Price and difficulties in preparation were also considered as obstacles in the occasional (36 and 28\%, 
respectively) and non-consumer groups (19\%). About a third in each category identified the influence of health professionals, health promotion activities and the mass media as being promoting factors for fish consumption. Only about a tenth was influenced by their social group to consume fish.

Approximately a third of participants almost never consumed foods enriched with n-3, such as bread, egg, yogurt, milk, spread and cereal (Figure 2). Of the participants that did consume n-3 enriched foods, milk, bread and spreads were the highest (Figure 2). Health benefit (47\%) was rated as being the most important factor influencing consumption of $n-3$ enriched food, followed by media (26\%), health promotion (25\%), health professional advice $(23 \%)$ and the influence of family members (18\%), while price (21\%) was rated as the main barrier (Figure $3)$.

Regarding preferred nutrition education strategies to improve their children's n-3 LCPUFA intake, participants identified cooking courses (35\%) and group discussions (18\%) and they also preferred types of accompanying materials such as recipe books (51\%), leaflets/brochures (47\%) and online programme materials (23\%).

\section{DISCUSSION}

The present survey has identified factors that influence decision-making of parents regarding provision of fish and seafood, and foods enriched with n-3 LCPUFA, to their children. Despite a high level of awareness regarding the health benefits of fish identified in the current study and others, ${ }^{48,49}$ only a fifth of participants reported eating fish and/or seafood at least twice per week, which is the recommendation for cardiovascular health. ${ }^{22,23}$ Intake of commercially available foods enriched with n-3 was similarly low. Nationally representative data has reported 
that Australian children and adolescents have low intakes of fish, ${ }^{24,25}$ which results in inadequate intakes of n-3 LCPUFA. ${ }^{25}$ A similar finding has been reported in younger pre-school children aged $1-5$ years, in which only $32 \%$ met the adequate intake for n-3 LCPUFA ${ }^{50}$ as well as in overweight and obese children aged $5-12$ years. ${ }^{51}$

Children have a strong influence on the type of foods prepared and consumed by families. It has been reported that young children's dislike of fish and seafood may lead to omission of this food group in the family meal repertoire, ${ }^{37,52}$ while the presence of adolescents in the home is more likely to result in the presence of negative perceptions associated with seafood, including smell during preparation, taste and reported overall family dislike of these foods. ${ }^{52}$ Further, larger households are associated with a greater dislike of fish and seafood, particularly if those households include children older than 8 years. ${ }^{37}$ It has been reported that parental involvement has some promising positive impacts in encouraging healthy eating practices in children ${ }^{30,31,34,35,53,54}$ as well as introducing novel foods enriched with EPA and DHA. $^{27}$

As well as frequency of fish consumption, we were interested in specific choices thereof, as the n-3 LCPUFA content differs substantially between species. Our data found that most families do not consume EPA and DHA-rich sources of fish and seafood, ${ }^{55}$ such as mackerel, herring, anchovies, sardines and oyster. Except for tuna (mostly canned) and salmon, oily fish was infrequently consumed. Nearly half of the sample reported consuming take-away fish and chips at least once a month, which is twice the frequency reported in $1999(27 \%) .{ }^{43}$ It is noteworthy that the method of cooking does not necessarily affect the amount of EPA and DHA in the fish, however, if the fish is fried using an n-6 oil (e.g. sunflower or safflower), the fish absorbs the n- 6 oil, such that the ratio of $n-3$ to $n-6$ decreases and this has been shown in fried 
salmon, ${ }^{56,57}$ codfish, hake, sole ${ }^{58}$ mackerel and sardines. ${ }^{57}$ Thus, the promotion of oily fish to improve n-3 LC PUFA intakes may require attention to cooking method thereof.

It is useful to analyse factors that affect consumption according to frequency of fish intake, in order to identify determinants of behaviour that may be targeted in intervention strategies targeted at families. For example, in those participants that frequently ate fish, the influence of a family member was rated as a driving factor, whereas this was perceived as an obstacle to consumption in the occasional or non-fish eating groups. It has been argued that decisions to consume fish are shaped by three influences, including "favourable attitude, high subjective norm and high perceived behavioural control", ${ }^{37}$ while, self-efficacy (confidence to consume) is a necessary predictive factor to consumption of novel sources of n-3 LCPUFA containing foods ${ }^{59,60}$ as well as the believe that behavioural change will reduce a health risk. ${ }^{59}$

Our findings regarding barriers to fish consumption are similar to other studies ${ }^{37-39,61}$ and include unpleasant physical properties of some varieties of fish (e.g. bones and smell), environmental concerns such as presence of pollutants, difficulties associated with preparation of fish, and the high cost. Price was identified as the most predominant barrier to consuming foods enriched with n-3 LCPUFA, but not for canned fish. In non-fish eaters, taste and allergy were important reasons, as has been reported by others, ${ }^{62}$ while cost and possibility of overdosing (i.e. erroneous assumption that you could consume too much n-3 LCPUFA from n-3 LCPUFA enriched foods) were the major barriers to eating foods enriched with n-3 LCPUFA. ${ }^{46}$ Australian consumers argue that external economic policy influences to reduce the price of fish commodities, and food policy that results in more informative labelling on foods (related to "free from contaminants", such as mercury) are required to empower consumers to change dietary practices associated with fish and seafood consumption. ${ }^{46,47}$ Similarly, clear labelling that 
convince consumers of the legislation controlling claims as well as the possibility of overdosing on n-3 enriched food package is required to motivate increased consumption thereof. ${ }^{46}$ Parents in the present study identified that improved cooking skills would be beneficial to encourage their family to eat more fish and n-3 enriched foods.

The main limitation of the study design relates to the use of a convenience sample, drawn from a single regional geographical location. However, external validity can be assessed by comparing the reported fish consumption habits with data from a nationally representative survey of 1025 Australian adults conducted by the Fisheries Research and Development Corporation (FRDC) in 2011, ${ }^{44}$ in which the same proportion of participants reported consuming fish more than once per week, namely a fifth.

\section{CONCLUSIONS}

Australian parents are knowledgeable about the health benefits of foods that contain n-3, especially fish, and are also aware of fish being a potential source of pollutants e.g. mercury. Strategies that attempt to alter dietary behaviour in children and adolescents need to focus on the identified barriers to consumption of n-3-rich foods, including perceived family dislike of taste, inconvenience associated with preparation (smell, bones), lack of cooking skills, and cost constraints. The high intake of canned fish variants may necessitate promotion of these alternatives within recipes or as snack foods by nutrition professionals.

\section{ACKNOWLEDGEMENTS}

We thank to the participants participated in this present study. We also thank to the Directorate General Higher Education Indonesia for sponsoring Setyaningrum Rahmawaty, a lecturer from 
the University of Muhammadiyah Surakarta Indonesia for her $\mathrm{PhD}$ at the University of Wollongong, New South Wales, Australia.

\section{COMPETING INTERESTS}

None identified. 
Table 1. Characteristic of participants $(n=262)$

\begin{tabular}{|c|c|c|}
\hline & $\mathrm{n}$ & $\%$ \\
\hline \multicolumn{3}{|l|}{ Nationality (country of birth used)* } \\
\hline Australia & 200 & 76.3 \\
\hline English & 11 & 4.2 \\
\hline Chinese & 5 & 1.9 \\
\hline European & 5 & 1.9 \\
\hline Indonesian & 4 & 1.5 \\
\hline Italian & 3 & 1.1 \\
\hline Indian & 3 & 1.1 \\
\hline Korean & 3 & 1.1 \\
\hline Thai & 3 & 1.1 \\
\hline Lebanese & 2 & 0.8 \\
\hline Turkish & 2 & 0.8 \\
\hline Sri Lankan & 2 & 0.8 \\
\hline Canadian & 2 & 0.8 \\
\hline Irish & 1 & 0.4 \\
\hline Scottish & 1 & 0.4 \\
\hline German & 1 & 0.4 \\
\hline Vietnamese & 1 & 0.4 \\
\hline American & 1 & 0.4 \\
\hline Argentinean & 1 & 0.4 \\
\hline Greek & 1 & 0.4 \\
\hline Macedonian & 1 & 0.4 \\
\hline Midle Costean & 1 & 0.4 \\
\hline New Zealander & 1 & 0.4 \\
\hline Persian & 1 & 0.4 \\
\hline Portuguese & 1 & 0.4 \\
\hline Saudi Arabia & 1 & 0.4 \\
\hline Spanish & 1 & 0.4 \\
\hline Swedish & 1 & 0.4 \\
\hline Welsh & 1 & 0.4 \\
\hline \multicolumn{3}{|l|}{ Age (years) } \\
\hline$<35$ & 52 & 20 \\
\hline $35-44$ & 162 & 62 \\
\hline $45-54$ & 48 & 18 \\
\hline \multicolumn{3}{|l|}{ Fish eater status } \\
\hline Frequent eaters (consume $\geq 2$ meals fish per week) & 54 & 21 \\
\hline Occasional eaters (consume $<2$ meals fish per week) & 181 & 69 \\
\hline Non-fish eater & 27 & 10 \\
\hline
\end{tabular}


Table 2. Frequency for consuming fresh or frozen fish or seafood products $(\%$ of total participants, $\mathrm{n}=262$ )

\begin{tabular}{lrrrrrrrr}
\hline & $\begin{array}{c}\text { Almost } \\
\text { never }\end{array}$ & $\begin{array}{c}\text { Once } \\
\text { a month }\end{array}$ & $\begin{array}{c}\text { 2 or 3 } \\
\text { times } \\
\text { a month }\end{array}$ & $\begin{array}{c}\text { Once } \\
\text { a week }\end{array}$ & $\begin{array}{c}\text { Twice } \\
\text { a week }\end{array}$ & $\begin{array}{c}3 \text { or } 4 \\
\text { times } \\
\text { a week }\end{array}$ & $\begin{array}{l}\text { Once } \\
\text { a day }\end{array}$ & Never \\
\hline Anchovies* & 76 & 5 & 1 & 1 & 0 & 0 & 0 & 16 \\
Mackerel* & 77 & 3 & 1 & 0.4 & 0 & 0 & 0 & 18 \\
Herring* & 77 & 3 & 2 & 0.4 & 0 & 0 & 0 & 18 \\
Salmon* & 34 & 27 & 18 & 8 & 1 & 0.4 & 0.4 & 10 \\
Tuna* & 45 & 16 & 12 & 6 & 2 & 3 & 0.4 & 14 \\
Sardines* & 76 & 3 & 2 & 0.4 & 0.4 & 0.4 & 0 & 18 \\
Shellfish* & 59 & 18 & 6 & 2 & 0.4 & 0 & 0 & 14 \\
Oyster* & 66 & 15 & 3 & 0.4 & 0 & 0.4 & 0 & 14 \\
Prawns* & 28 & 42 & 17 & 5 & 2 & 0 & 0 & 6 \\
Fish from fish & 34 & 40 & 15 & 5 & 0.4 & 0 & 0.4 & 5 \\
\& chips shop* & & & & & & & 0.4 & 0.4 \\
\hline
\end{tabular}

* Total $\%$ of participant below $100 \%$, because they did not answer the questions

Table 3. Frequency for consuming canned fish or seafood products ( $\%$ of total participants, $n=$ 262)

\begin{tabular}{lrrrrrrrr}
\hline & $\begin{array}{c}\text { Almost } \\
\text { never }\end{array}$ & $\begin{array}{c}\text { Once } \\
\text { a month }\end{array}$ & $\begin{array}{c}\text { 2 or 3 } \\
\text { times } \\
\text { a month }\end{array}$ & $\begin{array}{c}\text { Once } \\
\text { a week }\end{array}$ & $\begin{array}{c}\text { Twice a } \\
\text { week }\end{array}$ & $\begin{array}{c}3 \text { or } 4 \\
\text { times } \\
\text { a week }\end{array}$ & $\begin{array}{c}\text { Once } \\
\text { a day }\end{array}$ & Never \\
\hline Anchovies & 74 & 8 & 4 & 0.4 & 0 & 0 & 0 & 14 \\
Mackerel & 79 & 2 & 0.8 & 0.4 & 0 & 0 & 0 & 18 \\
Herring & 80 & 2 & 0.8 & 0 & 0 & 0 & 0 & 17 \\
Salmon & 47 & 25 & 11 & 6 & 3 & 0.4 & 0 & 8 \\
Tuna & 17 & 22 & 21 & 16 & 9 & 8 & 0.8 & 5 \\
Sardines* & 70 & 9 & 4 & 2 & 1 & 0 & 0 & 14 \\
Shellfish & 80 & 2 & 0.4 & 0 & 0.4 & 0 & 0 & 17 \\
Oyster & 76 & 6 & 2 & 0 & 0.8 & 0 & 0 & 16 \\
Prawns & 78 & 5 & 2 & 0.4 & 0 & 0 & 0 & 16 \\
Fish paste & 78 & 4 & 1 & 0.4 & 0.4 & 0 & 0 & 16 \\
\hline
\end{tabular}

* Total $\%$ of participant below $100 \%$, because they did not answer the questions 


\section{Frequent eater (n - 54)}

\section{口Pcolttve DNegetbe}

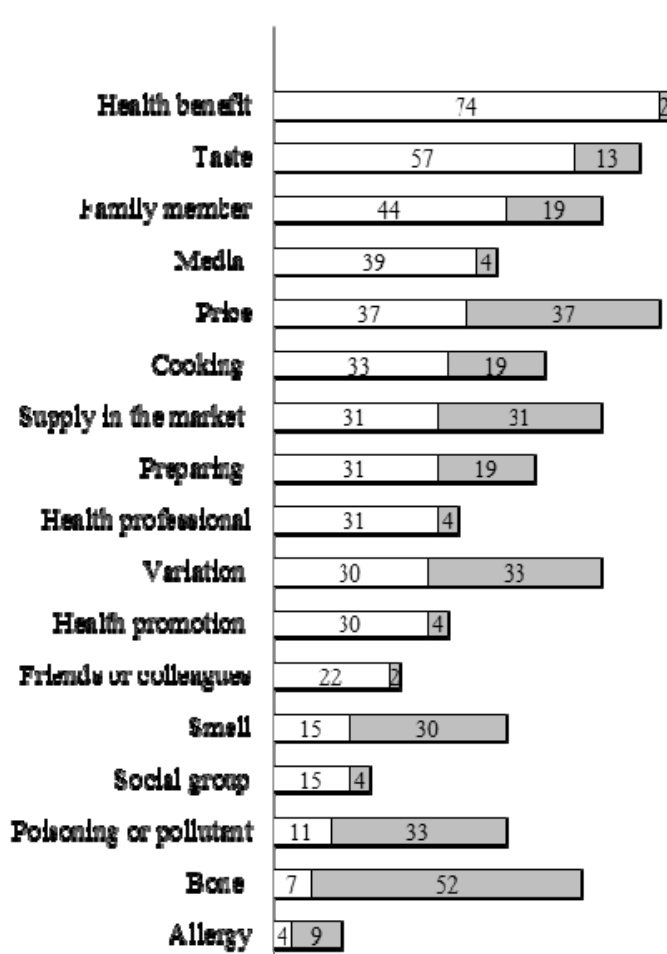

Occasional eater $(n=181)$

$\square$ Positive $\square$ Negative

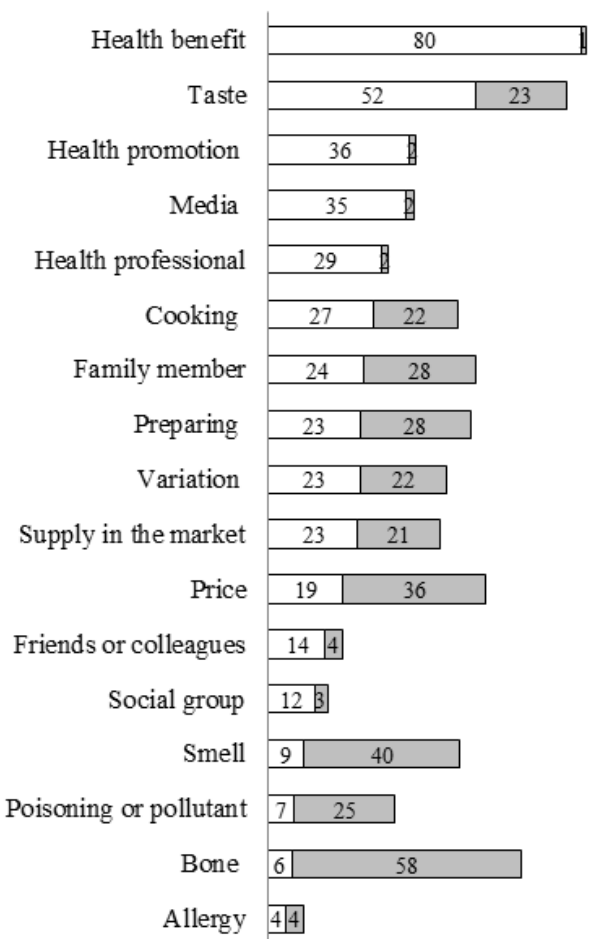

Non-fish eater $(n=27)$

$\square$ Negative $\square$ Positive

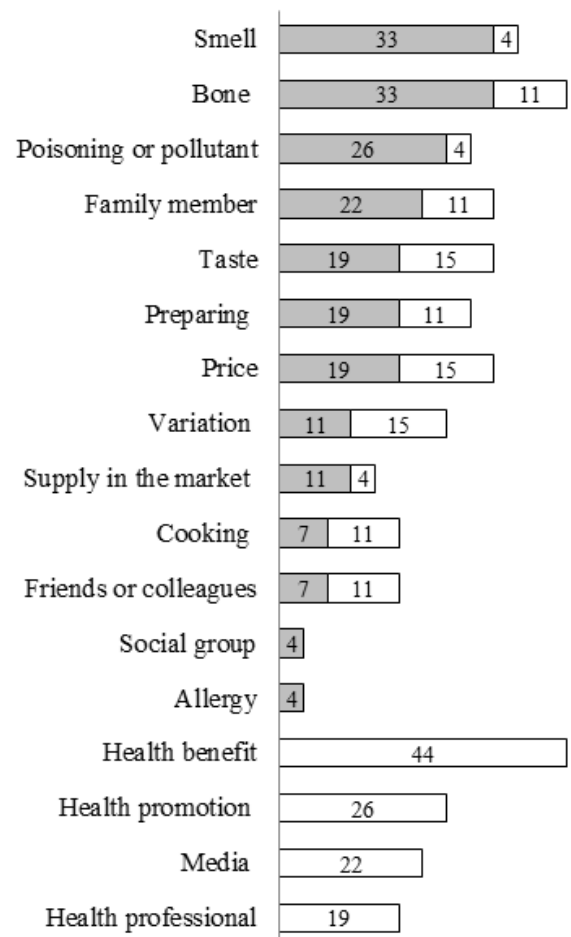

3 Fig. 1A. Factors that encourage (positive) and prevent (negative) for consuming fresh/frozen fish/seafood (\% of respondents)

4 Frequent eater, consume $\geq 2$ meals fish per week; Occasional eater, consume $<2$ meals fish per week; Non-fish eater, did not eat fish 


\section{Frequent eater $(n=54)$}

$\square$ Positive $\square$ Negative

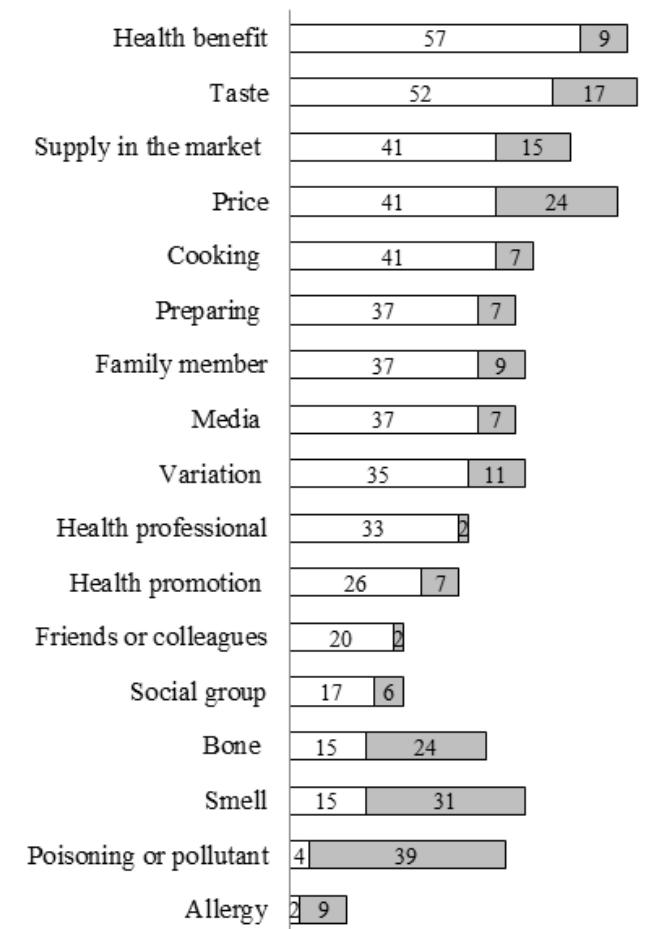

Occasional eater $(n=181)$

$\square$ Positive $\square$ Negative

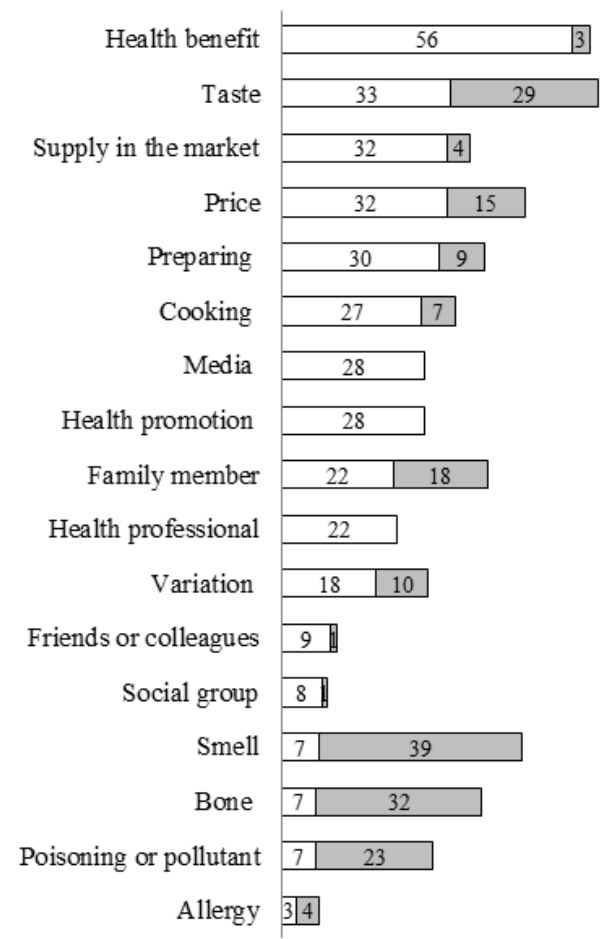

\section{Non-fish eater $(n=27)$}

$\square$ Negative $\square$ Positive

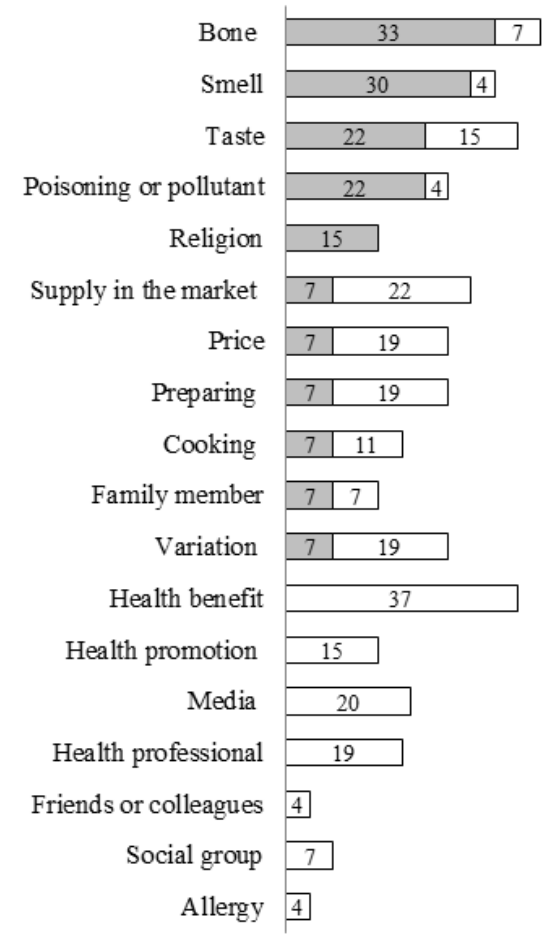

7

9 Fig. 1B. Factors that encourage (positive) and prevent (negative) for consuming canned fish/seafood (\% of respondents)

10 Frequent eater, consume $\geq 2$ meals fish per week; Occasional eater, consume $<2$ meals fish per week; Non-fish eater, did not eat fish 


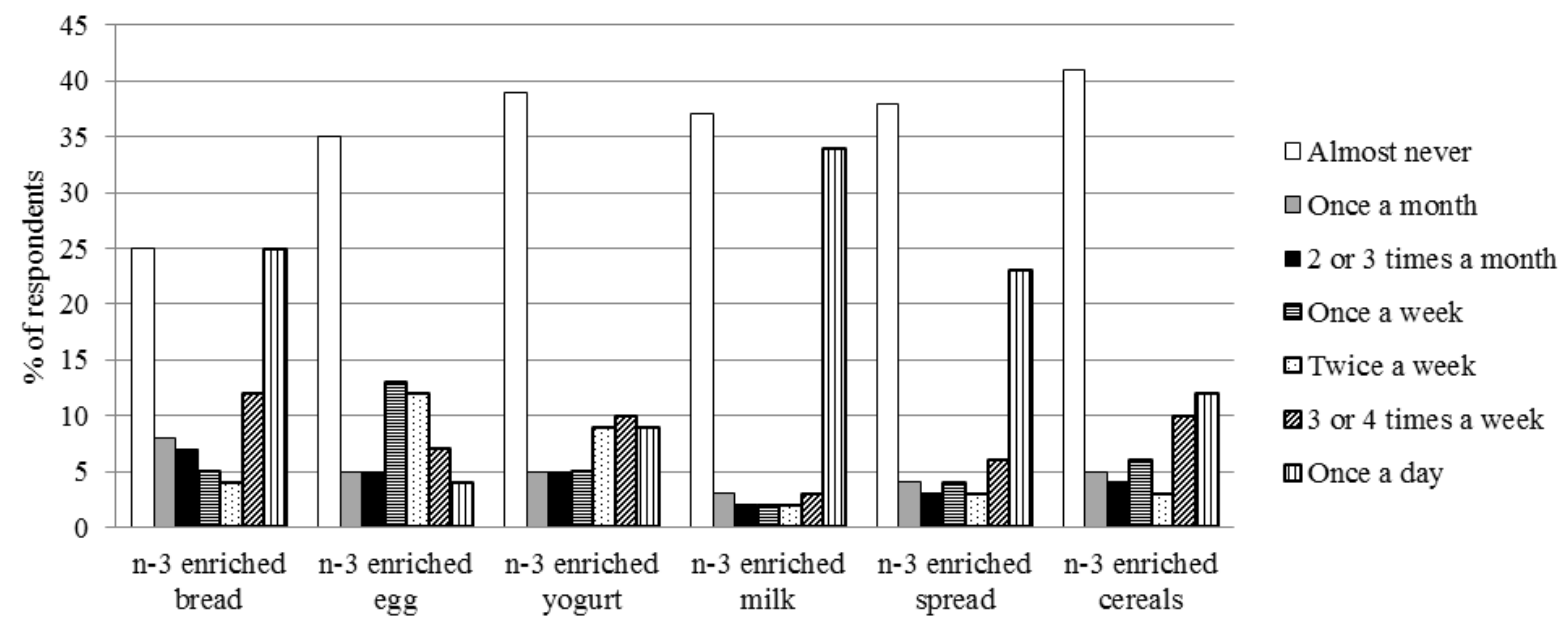

Fig. 2. Frequency for consuming omega-3 enriched foods ( $\%$ of total respondents, $n=262)$

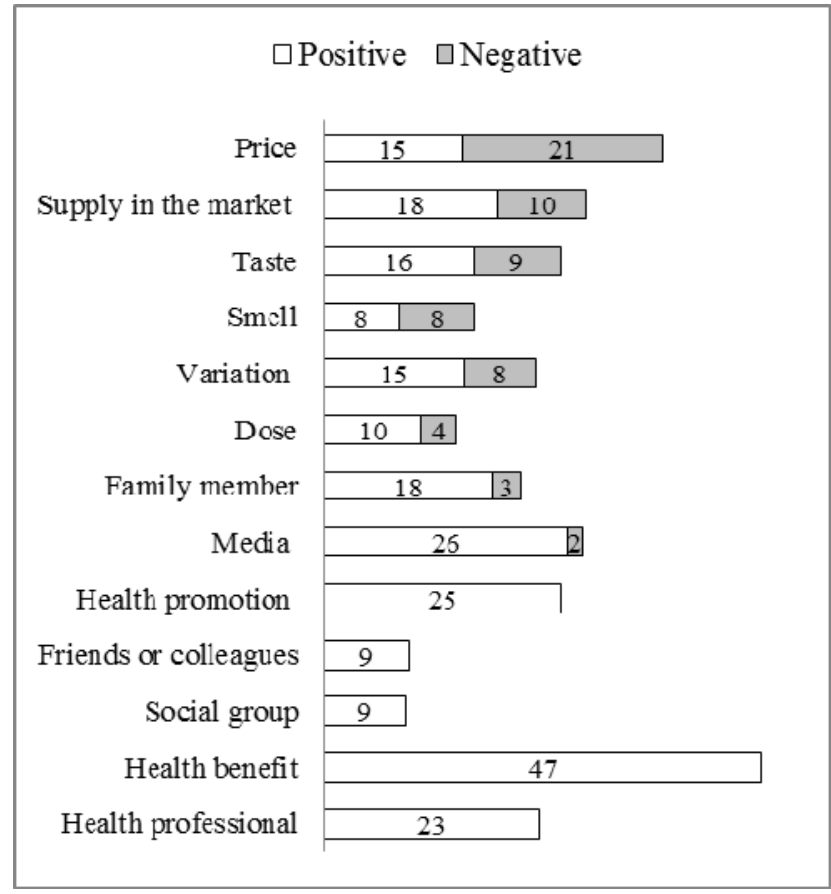

Fig. 3. Factors that encourage (positive) and prevent (negative) for consuming omega-3 enriched foods ( $\%$ of total respondents, $n=262)$ 
${ }^{1}$ Murakami K, Miyake Y, Sasaki S, Tanaka K, Arakawa M. Fish and n-3 Polyunsaturated Fatty Acid Intake and Depressive Symptoms: Ryukyus Child Health Study. Pediatrics 2010; 126: e623-e630.

${ }^{2}$ Kim JL, Winkvist A, Åberg MA et al. Fish consumption and school grades in Swedish adolescents, a study of the large general population. Acta Paediatr 2010; 99: 72-77.

${ }^{3}$ Åberg MA, Åberg N, Brisman J, Sundberg R, Winkvist A, Torén K. Fish intake of Swedish male adolescents is a predictor of cognitive performance. Acta Paediatr 2009; 98: 555-560. ${ }^{4}$ Dalton A, Wolmarans P, Witthuhn RC, Stuijvenberg ME, Swanevelder SA, Smuts CM. A randomised control trial in schoolchildren showed improvement in cognitive function after consuming a bread spread, containing fish flour from a marine source. Prostaglandins Leukot Essent Fatty Acids 2009; 80: 143-149.

${ }^{5}$ Groot RHM, Ouwehand C, Jolles J. Eating the right amount of fish: Inverted U-shape association between fish consumption and cognitive performance and academic achievement in Dutch adolescents. Prostaglandins Leukot Essent Fatty Acids 2012; 86: 113-7.

${ }^{6}$ Gump BB, MacKenzie JA, Dumas AK et al. Fish consumption, low-level mercury, lipids, and inflammatory markers in children. Environ Res 2012; 112: 204-211.

${ }^{7}$ Romeo J, Wärnberg J, Garci'a-Ma'rmol E et al. Daily consumption of milk enriched with fish oil, oleic acid, minerals and vitamins reduces cell adhesion molecules in healthy children. Nutr Metab Cardiovasc Dis 2011; 21: 113-120.

${ }^{8}$ Burrows T, Collins CE, Garg ML. Omega-3 index, obesity and insulin resistance in children. Int J Pediatr Obes 2011; 6: e532-e539. 
${ }^{9}$ Pawlosky RJ, Hibbeln, Novotny JA, Salem N. Physiological compartmental analysis of $\alpha-$ linolenic acid metabolism in adult humans. J Lipid Res 2001; 42: 1257-1265.

${ }^{10}$ Burdge GC, Finnegan YE, Minihane AM, Williams CM, Wootton SA. Effect of altered dietary n-3 fatty acid intake upon plasma lipid fatty acid composition, conversion of $\left[{ }^{13} \mathrm{C}\right] \alpha$ linolenic acid to longer-chain fatty acids and partitioning towards $\beta$-oxidation in older men. $\mathrm{Br} J$ Nutr 2003; 90: 311-321.

${ }^{11}$ Meyer BJ, Mann NJ, Lewis JL, Milligan GC, Sinclair AJ, Howe PRC. Dietary intakes and food sources of omega-6 and omega-3 polyunsaturated fatty acids. Lipids 2003; 38: 391-398.

${ }^{12}$ Rahmawaty S. Dietary intake and food sources of omega-3 long chain EPA, DPA and DHA of Australian children. University of Wollongong, $\mathrm{PhD}$ Thesis 2012 (unpublished)

${ }^{13}$ Lovegrove JA, Brooks CN, Murphy MC, Gould BJ, Williams CM. Use of manufactured foods enriched with fish oils as a means of increasing long-chain $n-3$ polyunsaturated fatty acid intake. Br J Nutr 1997; 78: 223-236.

${ }^{14}$ Amiano P, Dorronsoro M, M de Renobales, Ruiz de Gordoa JC, Irigoien I, the EPIC Group of Spain. Very-long-chain $\omega-3$ fatty acids as markers for habitual fish intake in a population consuming mainly lean fish: the EPIC cohort of Gipuzkoa. Eur J Clin Nutr 2001; 55: 827-832. ${ }^{15}$ Oddy WH, Sherriff JL, Kendall GE et al. Patterns of fish consumption and level of serum phospholipid very-long-chain omega-3 fatty acids in children with and without asthma, living in Perth, Western Australia. Nutr Diet 2004; 61: 30-37.

${ }^{16}$ Yep YL, Li D, Mann NJ, Bode O, Sinclair AJ. Bread enriched with microencapsulated tuna oil increases plasma docosahexaenoic acid and total omega-3 fatty acid in humans. Asia Pac J Clin Nutr 2002; 11: 285-291. 
${ }^{17}$ Gillingham LG, Caston L, Leeson S, Hourtovenko K, Holub BJ. The effects of consuming docosahexaenoic acid (DHA)-enriched eggs on serum lipids and fatty acid composition in statintreated hypercholesterolemic male patients. Food Res International 2005; 38: 1117-1123.

${ }^{18}$ Baró L, Fonallá J, Peña JL et al. n-3 fatty acids plus oleic acid supplemented milk reduces total and LDL cholesterol, homocysteine and levels of endothelial adhesion molecules in healthy humans. Clin Nutr 2003; 22: 175-182.

${ }^{19}$ Garg ML, Blake RJ, Clayton E et al. Consumption of an n-3 polyunsaturated fatty acidenriched dip modulates plasma lipid profile in subjects with diabetes type II. Eur J Clin Nutr 2007; 61: 1312-1317.

${ }^{20}$ Murphy K, Meyer BJ, Mori TA et al. Impact of foods enriched with omega-3 long chain polyunsaturated fatty acids on erythrocyte omega-3 levels and cardiovascular risk factors. $\mathrm{Br} J$ Nutr 2007; 97: 749-757.

${ }^{21}$ Australian Government, Department of Health and Ageing, National Health and Medical Research Council (2005) Food for health, dietary guidelines for Australian, a guide to healthy eating. Available at: http://www.nhmrc.gov.au/_files_nhmrc/publications/attachments/n31.pdf: accessed on February 2012.

${ }^{22}$ Colquhoun D, Ferreira-Jardim A, Udell T, Eden B, the Nutrition and Metabolism Committee of the Heart Foundation. Review of evidence fish, fish oils, n-3 pollyunsaturated fatty acids and cardiovascular health. NHFA 2008. Available at: www.heartfoundation.org.au: accessed on December 2011.

${ }^{23}$ National Health Foundation of Australia. Position statement, fish, fish oils, $n-3$ polyunsaturated fatty acids and cardiovascular health. NHFA 2008. 
${ }^{24}$ Clayton EH, Hanstock TL, Watson JF. Estimated intakes of meat and fish by children and adolescents in Australia and comparison with recommendations. Br J Nutr 2009; 101:1731-1735. ${ }^{25}$ Meyer BJ, Kolanu N. Australian children are not consuming enough long-chain omega-3 polyunsaturated fatty acids for optimal health. Nutrition 2011; 27: 1136-1140.

${ }^{26}$ Lovegrove JA, Brooks CN, Murphy MC, Gould BJ, Williams CM. Use of manufactured foods enriched with fish oils as a means of increasing long chain n-3 polyunsaturated fatty acid intake. Br J Nutr 1997; 78: 223-236.

${ }^{27}$ Patch CS, Tapsell LC, Mori TA et al. The Use of Novel Foods Enriched with Long-Chain n-3 Fatty Acids to Increase Dietary Intake: A Comparison of Methodologies Assessing Nutrient Intake. J Am Diet Assoc 2005; 105: 1918-1926.

${ }^{28}$ Birch LL. Preschool children's food preferences and consumption patterns. J Nutr Educ. 1979;11:189-192.

${ }^{29}$ Skinner JD, Carruth BR, Bounds W, Ziegler PJ. Children's food preferences: A longitudinal analysis. J Am Diet Assoc 2002; 102: 1638-1647.

${ }^{30}$ Kral TVE, Rauh EM. Eating behaviour of children in the context of their family environment. Phy and Behav 2010; 100: 567-573.

${ }^{31}$ Savage JS, Fisher JO, Birch LL. Parental influence on eating behaviour: conception to adolescence. J Law Med Ethics 2007; 35: 22-34.

${ }^{32}$ Imm P, Knobeloch L, Anderson HA. Maternal recall of children's consumption of commercial and sport-caught fish: Findings from a multi-state study. Environ Res 2006; 103: 198-204.

${ }^{33}$ Birch LL. Development of food preferences. Annu Rev Nutr 1999; 9: 41-62.

${ }^{34}$ Gilman M, Rifas-Shiman S, Frazier L et al. Family dinner and diet quality among older children and adolescents. Archives Family Med 2000; 9: 235-240. 
${ }^{35}$ Jenkin S, Horner SD. Barriers that influence eating behaviours in adolescents. J Paediatr Nurs $2005 ; 20: 258-267$.

${ }^{36}$ Leek S, Muddock S, Foxall G. Situational determinants of fish consumption. Br J Food 2000; 102: 18-39.

${ }^{37}$ Verbeke W, Vackier I. Individual determinants of fish consumption: application of the theory of planned behaviour. Appetite 2005; 44: 67-82.

${ }^{38}$ Trondsen T, Scholderer J, Lund E, Eggen AE. Perceived barriers to consumption of fish among Norwegian women. Appetite 2003; 41: 301-314.

${ }^{39}$ Prell H, Berg C, Jonsson L. Why don't adolescents eat fish? Factors influencing fish consumption in school. Scandinavian J Articles 2002; 46: 184-191.

${ }^{40}$ Pliner P, Salvy SJ. Food neophobia in humans. In R Shepherd, M Raats (Eds). The psychology of food choice (pp. 75-92). Oxfordshire: CABI, 2006.

${ }^{41}$ Knaapila A, Silventoinen K, Broms U et al. Food neophobia in young adults: genetic architecture and relation to personality, pleasantness and use frequency of foods, and body mass index - A twin study. Behav Genet 2011; 41: 512-521.

${ }^{42}$ Fisheries Research and Development Corporation. A study of the retail sale and in home consumption of seafood in Sydney. Canberra, Commonwealth Dept of Agriculture, Fishery and Forestry, 1998.

${ }^{43}$ Fisheries Research and Development Corporation. A study of seafood consumption in Perth. Canberra, Commonwealth Dept of Agriculture, Fishery and Forestry, 1999.

${ }^{44}$ Fisheries Research and Development Corporation. Community perceptions of the sustainability of the fishing industry in Australia. April 2011. 
${ }^{45}$ Howe P, Buckley J, Meyer B. Red meat: a source of long chain omega-3. Nutr Diet 2007; 64: S135-139.

${ }^{46}$ Patch CS, Tapsell LC, Williams PG. Overweight consumers' salient beliefs on omega-3enriched functional foods in Australia's Illawarra region. J Nutr Educ Behav 2005; 37: 83-89. ${ }^{47}$ Cox DN, Evans G, Lease HJ. Predictors of Australian consumers' intentions to consume conventional and novel sources of long-chain omega-3 fatty acids. Public Health Nutr 2008; 11: 8-16.

${ }^{48}$ Mozaffarian D, Rimm EB. Fish intake, contaminants, and human health evaluating the risks and the benefits. J Am Med Assoc 2006; 296: 1885-1899.

${ }^{49}$ Food and Agriculture OrganizationWorld Health Organization. Report of the joint FAO/WHO expert consultation on the risk and benefits of fish consumption, 25-29 January 2010, Rome, Italy. FAO Fisheries and Aquaculture Report 2011, No 978.

${ }^{50}$ Zhou SJ, Gibson RA, Gibson RS, Makrides M. Nutrient intakes and status of preschool children in Adelaide, South Australia. MJA 2012; 196: 696-700.

${ }^{51}$ Burrows T, Berthon B, Garg ML, Collins CE. A comparative validation of a child food frequency questionnaire using red blood cell membrane fatty acids. Eur J Clin Nutr 2012; 66: $852-829$.

${ }^{52}$ Myrland O, Trondsen T, Johnston R, Lund E. Determinants of seafood consumption in Norway: lifestyle, revealed preferences and barriers to consumption. Food Quality and Pref $2000 ; 11: 169-188$.

${ }^{53}$ Wang Y, Beydoun MA, Li J, Liu Y, Moreno LA. Do children and their parents eat a similar diet? Resemblance in child and parental dietary intake: systemic review and meta-analysis. $J$ Epid Comm Health 2011; 65: 177-189. 
${ }^{54}$ Scaglioni eS, Arrizza C, Vecchi F, Tedeschi S. Determinants of children's eating behaviour. Am J Clin Nutr 2011; 94: 206S-11S.

${ }^{55}$ National Health Foundation of Australia. Omega-3 levels in fish and seafood. NHFA 2008. http://www.heartfoundation.org.au/SiteCollectionDocuments/Omega3levelsinfishandseafood.pdf : access on 31 March 2012

${ }^{56}$ Gladyshev MI, Sushchik NN, Gubanenko GA, Demirchieva SM, Kalachova GS. Effect of way of cooking on content of essential polyunsaturated fatty acids in muscle tissue of humpback salmon (Oncorhynchus gorbuscha). Food Chem 2006; 96: 446-451.

${ }^{57}$ Candella M, Astiasarán I, Bello J. Deep-fat frying modifies high-fat fish lipid fraction. J Agri Food Chem 1998; 46: 2793-2796.

${ }^{58}$ Candela M, Astiasarán I, Bello J. Effects of frying and warmholding on fatty acids and cholesterol of sole (Solea solea), codfish (Gadus morrhua) and hake (Merluccius merluccius). Food chem 1997; 58: 227-231.

${ }^{59}$ Krutulyte R, Grunert KG, Scholderer J et al. Motivational factors for consuming omega-3 PUFAs: An exploratory study with Danish consumers. Appetite 2008; 51: 137-147.

${ }^{60}$ Cox DN, Evans G, Lease HJ. Predictors of Australian consumers' intention to consume conventional and novel sources of long-chain omega-3 fatty acids. Public Health Nutr 2007; 11: $8-16$.

${ }^{61}$ Brunsø. Motives, barriers and quality evaluation in fish consumption situations: Exploring and comparing heavy and light users in Spain and Belgium. Br Food J 2009; 7: 699-716.

${ }^{62}$ Aslin HJ, Byron IG. Community perceptions of fishing: implication for industry image, marketing and sustainability. Fisheries Research and Development Corporation and Bureau of Rural Statistic 2003. 
